\title{
Reoccurrence of Marine Leech Zeylanicobdella Argumensis, A Marine Fish Parasite Following a Freshwater Bath
}

\author{
Kua Beng Chu*, Muhd. Naim Abd. Malek and Horng Chung Kok \\ National Fish Health Research Center (NaFisH), Fisheries Research Institute, Malaysia \\ *Corresponding author: Kua Beng Chu, NaFisH, Fisheries Research Institute, Malaysia
}

\section{ARTICLE INFO}

Received: 幽 November 04, 2019

Published: 慧 November 12, 2019

Citation: Kua Beng Chu, Muhd. Naim Abd. Malek, Horng Chung Kok. Reoccurrence of Marine Leech Zeylanicobdella Argumensis, A Marine Fish Parasite Following a Freshwater Bath. Biomed J Sci \& Tech Res 22(4)-2019. BJSTR. MS.ID.003794.

Keywords: Tiger Grouper; Marine Leech; Adult; Juvenile; Cocoon; Freshwater Bath

\begin{abstract}
Freshwater bath had been practised by local marine fish culturists in order to dislodge ectoparasites. It is a prophylatic measure in fish health management on marine floating cages. However, the effectiveness of this freshwater bath treatment against the marine leech infectation is yet to be proven. The present study was carried out to determine the survival percentage of adult and juvenile marine leech exposed to freshwater bath. The hatching percentage of juvenile marine leech from cocoon laid in different time of day and exposed to freshwater was also studied. Results showed that $38-100 \%$ of adult and $60-100 \%$ of juvenile marine leech were able to recover in seawater. Results of the hatching percentage showed a lower hatching rate $(27.5 \%)$ on the Day 1 cocoon treated with freshwater as against 81.6, 77.0, 74.7 and $61.7 \%$ in control (no freshwater bath), Day 3, 5 and 7 respectively. There was a significant difference in hatching percentage between the cocoon laid time of day as compared to the freshwater bath. However, there was no significant difference between the exposure time $[5,30$ and 60 minutes) with hatching percentage of cocoon. This study showed that a 5- to10minute freshwater bath could reduce the marine leech. However, reinfection can occur as 25 to $33 \%$ of adult and 17 to $50 \%$ of juvenile marine leech are able to infect the fish after freshwater bath. A delay of freshwater treatment on the laid cocoon after day 1 onward would increase the hatching rate of juvenile marine leech, hence increasing its population in the cultured fish.
\end{abstract}

\section{Introduction}

Marine leech, Z. argumensis is a parasite with a direct life cycle on the fish body. It infests most of the cultured species (Epinephelus coioides, E. lanceolatus, E. fuscoguttatus, Lutjanus johnii, L. argentimaculatus, L. erytropterus, L. stellatus and Lates calcarifer) and under temperature of $27^{\circ} \mathrm{C}$, it needs 16 to 17 days to complete the life cycle [1]. Marine leech infestation can be reduced through freshwater bath by removing/killing the adult and juvenile or reducing the hatching rate of the juvenile from the cocoon. Freshwater bath is commonly used as a prophylaxis to minimize parasitic diseases in marine fish culture. Practically, freshwater bath works by rupturing the cell membranes of the parasites with influx of freshwater via osmosis. However, it could be detrimental to the fish if they are already under stress from being infected and the sudden change in salinity may kill the fish instead. Effectiveness of freshwater baths has been reported on cultured marine fish infected with sea lice or capsalid monogenean species [2,3].
In Japan, routine freshwater bathing at intervals of 14 days was introduced to amberjack (Seriola dumerili) and yellowtail (S. quinqueradiata) cultured in net pens in order to prevent body monogenea (Neobenedenia girellae). Freshwater bathing for 2 to 4 hours was also reported being able to reduce amoebic gill diseases in cultured altlantic salmon [4,5]. Leong et al. [6] reported 2-5 minutes freshwater dip could dislodge the body monogenea from the host fishes. In Malaysia, it has been used and included in fish health management by marine aquaculturist in tropical country as it is the simplest and fastest way to reduce the numbers of protozoan, flukes and lice that parasitized on marine fish or newly acquired fish. However, no documentation on the effectiveness of freshwater bath against the marine leech even through farmers have been practising it. The present study aims to determine the survival of adult, juvenile and percentage hatching in juvenile marine leech on cocoon aged day 1, 3, 5 and 7 in freshwater bath. The information 
is important as it can be used as a guideline for farmers to carry out the control measure of marine leech infection in tiger grouper.

\section{Materials and Methods}

\section{Source of Adult and Juvenile Marine Leech Z. arugamensis}

Marine leech Z. arugamensis were procured from the fish cages at Pulau Jerajak, (Latitude $5^{\circ} 18^{\prime} 57.67^{\prime \prime} \mathrm{N}$ and Longitude $100^{\circ} 18^{\prime} 30.48^{\prime \prime}$ ) Penang in Peninsular Malaysia. A tiger grouper (15 to $340 \mathrm{~g}$ ) infected with marine leeches were collected from fish cages and were placed in a petri dish containing seawater from the cage and leeches were removed individually by hand The adult leeches were transferred into a container with filtered sea water from the site and brought back to the laboratory for use in survival experiment and establishment of their life cycle for juvenile specimen based on Kua et al. [1]. Briefly, the active adult leeches were chosen and placed in $500 \mathrm{ml}$ jar with filtered seawater at 28 parts per thousand (ppt) salinity obtained from the sites and incubated at $27^{\circ} \mathrm{C}$ for 24 hours. Adult leeches were removed after 24 hours leaving the deposited cocoons on the glass wall or bottom of the jar for another 7 days to complete of the juvenile stage. Water was exchanged 50-60\% every 2 days with new sterile filtered seawater. During incubation, the deposited cocoons were kept in an incubator at $27^{\circ} \mathrm{C}$ for 7 - 8 days. After Day 7, the juvenile hatched from the cocoon and ready for the survival experiment in freshwater bath.

\section{Experiment of Survival of Adult and Juvenile Marine Leech in Freshwater Bath}

Adult marine leeches were bathed with freshwater $(250 \mathrm{ml})$ for duration of 5 to 10 minutes and their movement recorded immediately. Marine leech were transferred into seawater with 28 ppt salinity $(250 \mathrm{ml})$ when no movement was seen. An uninfected tiger grouper $(2-3 \mathrm{~cm})$ was placed in for infection study. Time and number of leeches showing movement and infecting the fish were recorded. The same experiment was conducted for juvenile marine leech.

\section{Percentage of Juvenile Hatched from Treated Cocoon}

The cocoons were obtained from the tiger grouper infected with marine leech in floating cages. A total of 100 clean glass slides were placed parallel each side of the tray and hung inside the cage. After 24 hours, approximately 80 slides containing cocoons on it were removed and placed into aquarium tank with seawater (28 - $30 \mathrm{ppt}$ ) from the cages and aerated. These slides were left in the aquarium tank and removed daily for the freshwater bath treatment. The slide containing more than 3 cocoons were chosen for the freshwater treatment. A total of 8 slides with cocoons aged 24 hours were taken out from the aquarium tank and subjected to freshwater bath with exposure time of 0 (control), 5, 30 and 60 minutes running in duplicates. The slides (each with 6 cocoons) were immersed in freshwater for 5 minutes in conical tube $(50 \mathrm{ml})$, then replaced it into conical tube $(50 \mathrm{ml})$ containing seawater from cages. The seawater was changed daily. The numbers of the cocoons on each slide were recorded before bathing in freshwater. The numbers of the hatched juvenile were also recorded for up to 14 days. The hatching percentages were based on the number of juvenile hatched divided by the number of cocoons exposed to freshwater. The above experiment was repeated for the cocoon aged day 3, 5 and 7. The experiment was terminated after day 14 .

\section{Statistical Analysis}

The hatching percentage of juvenile marine leech was analysed using Anova-one way with SPSS software. Results were considered siginifcant if $\mathrm{p}<0.05$. Tukey HSD was used for comparison of means.

\section{Results and Discussion}

Adult and juvenile marine leeches were able to recover after 3 to 10 minutes in freshwater bathing with a surival rate of 38 to $100 \%$ in adult marine leech and 60 to $100 \%$ in the juvenile when returned to seawater (Table 1). Of these, only 20 to $33 \%$ of survived adult and 17 to $50 \%$ of juvenile were able to infect fish after 30 minutes in seawater. No movement of adult marine leech was observed during the 5 to10 minutes bath in freshwater and it took 3 to 9 minutes for them to become active again in $28 \mathrm{ppt}$ seawater. As for juvenile marine leech, a shorter period of recovery time (1 to 3 minutes) were seen after freshwater bathing (Table 1). Results of the percentage of juvenile marine hatched from cocoon laid in different time of day showed that all of the juvenile were able to hatch regardless of the different aged of cocoon treated with freshwater bath. Similarly, the same percentage was seen in cocoon receiving no freshwater bath. However, the lower hatching percentage $(27.5 \%)$ was seen in the Day 1 laid cocoon treated with freshwater as compared with 81.6, 77.0, 74.7 and 61.7\% in control (no freshwater bath), Day 3, 5 and 7 respectively (Figure 1).

Table 1: Observation of survival rate (\%) of adult and juvenile marine leech in freshwater bath.

\begin{tabular}{|c|c|c|c|c|c|c|}
\hline \multirow[b]{2}{*}{ Stage } & \multirow[b]{2}{*}{ Trial } & \multirow[b]{2}{*}{$\begin{array}{l}\text { Number of Marine } \\
\text { Leech Exposed to } \\
\text { Freshwater Bath }\end{array}$} & \multicolumn{4}{|c|}{ Observations } \\
\hline & & & $\begin{array}{c}\text { *No/Passive Movement } \\
\text { in Freshwater } \\
\text { (Minutes) }\end{array}$ & $\begin{array}{l}{ }^{* *} \text { Active Movement in } \\
\text { Seawater (Minutes) }\end{array}$ & $\begin{array}{l}\text { Number of Marine } \\
\text { Leech Survival in } \\
\text { Seawater (\%) }\end{array}$ & $\begin{array}{l}\text { Number of Marine } \\
\text { Leech Attached to Fish } \\
\text { (\%) after } 30 \text { Minutes }\end{array}$ \\
\hline \multirow{5}{*}{ Adult } & 1 & 6 & 8 & 4 & $4(66.7)$ & $1(25.0)$ \\
\hline & 2 & 8 & 10 & 4 & $3(37.5)$ & $1(33.3)$ \\
\hline & 3 & 8 & 5 & 3 & $5(100.0)$ & $1(20.0)$ \\
\hline & Avearge \pm std & $7.3 \pm 1.2$ & $7.7 \pm 2.5$ & $3.7 \pm 0.6$ & $\begin{array}{c}4.0 \pm 1.0 \\
(68.1 \pm 31.3)\end{array}$ & $\begin{array}{c}1.0 \pm 0.0 \\
(26.1 \pm 6.7)\end{array}$ \\
\hline & Range & $6-10$ & $5-10$ & $3-9$ & $\begin{array}{c}3-5 \\
(38-100)\end{array}$ & $\begin{array}{c}1 \\
(20-33)\end{array}$ \\
\hline
\end{tabular}




\begin{tabular}{|c|c|c|c|c|c|c|}
\hline \multirow{7}{*}{ Juvenile } & 1 & 10 & 3 & 2 & $6(60.0)$ & $1(16.7)$ \\
\hline & 2 & 10 & 4 & 1 & $10(100.0)$ & $5(50.0)$ \\
\hline & 3 & 10 & 4 & 1 & $10(100.0)$ & $3(30.0)$ \\
\hline & 4 & 10 & 5 & 3 & $9(90.0)$ & $2(22.2)$ \\
\hline & 5 & 20 & 10 & 3 & $13(65.0)$ & $3(23.1)$ \\
\hline & Avearge \pm std & $12.0 \pm 4.5$ & $5.2 \pm 2.8$ & $2.0 \pm 1.0$ & $\begin{array}{c}9.6 \pm 2.5 \\
(83.0 \pm 19.2)\end{array}$ & $\begin{array}{c}2.8 \pm 1.5 \\
(28.4 \pm 13.0)\end{array}$ \\
\hline & Range & $10-20$ & $3-10$ & $1-3$ & $\begin{array}{c}6-13 \\
(60-100)\end{array}$ & $\begin{array}{c}1-5 \\
(17-50)\end{array}$ \\
\hline
\end{tabular}

Note: *No/passive movement: no movement of body but one or both suckers move. ${ }^{* *}$ Active movement: leech swim up and down.

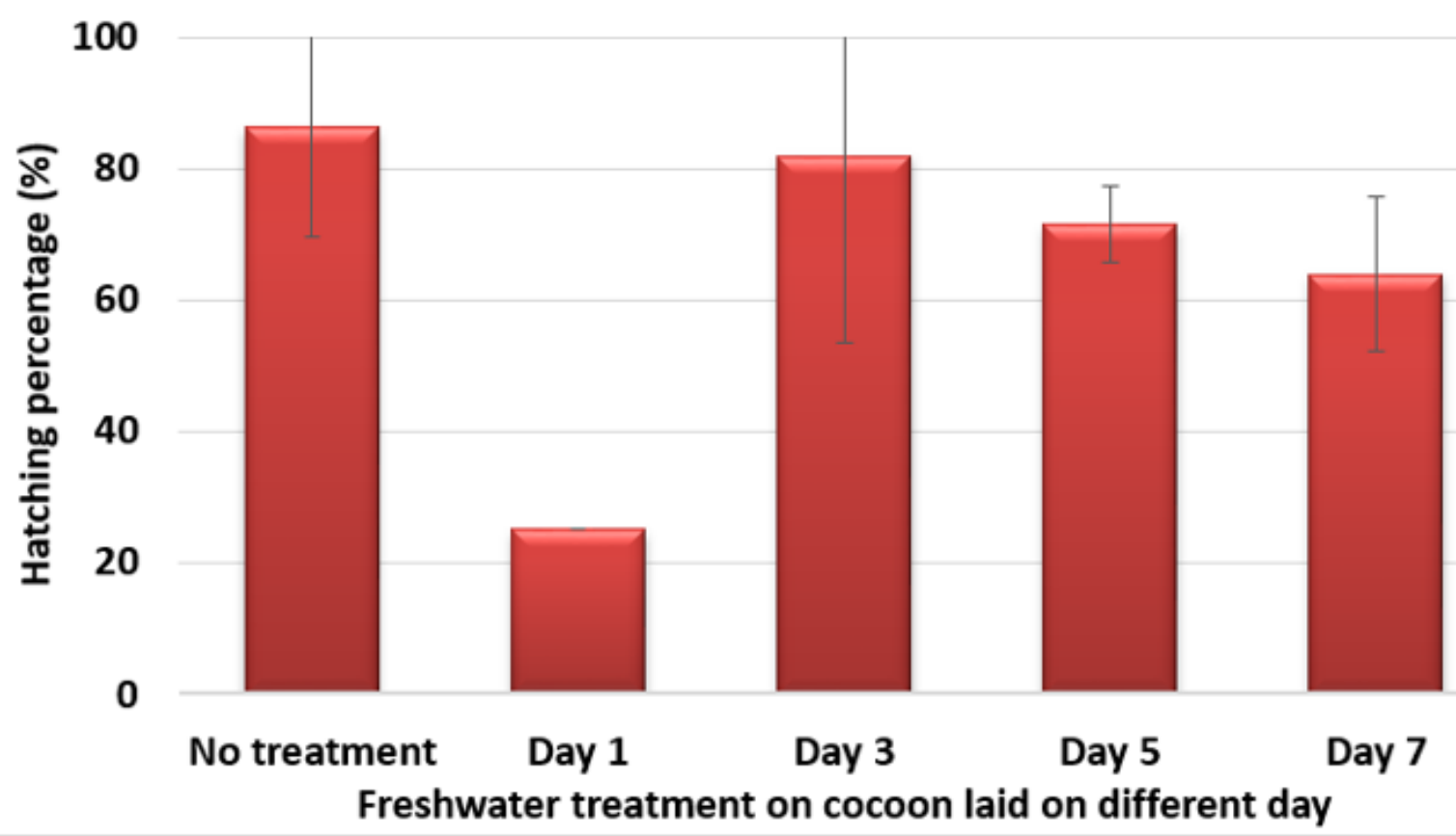

Figure 1: Hatching percentage of juvenile marine leech in freshwater treated cocoon laid on different day.

Hatching percentage in the Day 1 laid cocoon treated with freshwater was significantly lower and placed in an individual group after tested with Tukey HSD. However, no significant difference observed between the hatching percentage of cocoon against different cocoon laid time of day as compared with exposure duration (5, 30 and 60 minutes). This indicated that exposure time of 5,10 and 30 minutes of coccon in freshwater did not influence the hatching percentage of juvenile. Cruz-Lacierda, et al. [7] reported that regular freshwater bath treatment was not effective to kill leech in grouper as compared with 50ppm formalin bath treatment for one hour. However, formalin treatment was not popular among the farmers of floating cages. Instead, most cage farmers in Malaysia claimed that freshwater bathing could reduce the marine leech infection effectively in marine cultured fish. This was confirmed by less number of adult marine leech attached on the body surface of the treated fish. The present study showed that adult and juvenile of marine leech were not totally killed during the 5 to 10 minutes bath in freshwater. And the re-infection of marine leech will occur at a lower rate. This indicated that freshwater bath could reduce the adult leech population but a routine freshwater bathing at intervals of 14 days was needed to prevent marine leech infection.

Hatching rate of juvenile from the cocoon was $83.87 \%$ under laboratory condition and 17 - 18 days needed to complete their life cycle [1]. This high percentage of hatching juvenile will increase the population of marine leech in floating cages and thus increasing the risk of marine leech infection. Burreson, et al. [8] reported that cocoons of leech are very resistant to chemical treatment, but it can be eliminated by thorough drying of culture facilities. In floating cages, most farmers in Southeast Asian used high pressurized water jet to clean and remove the barnacles that attached to the net. This washing also helps to remove the attached cocoon from the net, but it does not break the life cycle of marine leech as the water flows back to the same culture site. The present study showed that lower juvenile were hatched from cocoon treated in freshwater 
bath on cocoon aged Day-1 as compared with cocoon aged Day-3, 5 and 7. The results also indicated that freshwater bath should be applied within 24-hours once cocoons were seen in the net or any substrate in the cages. Upon delaying the freshwater bath, a higher infestation of marine leech is expected. Exposure time regardless of 5, 1030 or 60 minutes did not influence the hatching percentage of juvenile.

\section{References}

1. Kua BC, Muhd AA, Khalidah N (2010) Life cycle of marine leech (Zeylanicobdella arugamensis) isolated from body of sea bass (Lates calcarifer) under laboratory conditions. Aquaculture 302(3-4): 153-157.

2. Pironet $\mathrm{F}$, Jones J (2000) Treatments for ectoparasites and disease in captive western Australian dhufish. Aquatic Int 8(4): 349-361.

3. Ernst I, Whittington ID, Corneillie S, Talbot C (2002) Monogenean parasites in sea-cage aquaculture. Austasia Aqauculture 16: 46-48.

ISSN: 2574-1241

DOI: 10.26717/BJSTR.2019.22.003794

Kua Beng Chu. Biomed J Sci \& Tech Res

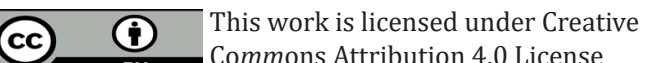

Submission Link: https://biomedres.us/submit-manuscript.php
4. Parsons H, Nowak B, Fisk D, Powell M (2001) Effectiveness of commercial freshwater bathing as a treatment against amoebic gill disease in Atlantic salmon. Aquaculture 195(3-4): 205-210.

5. Clark G, Powell M, Nowak B (2003) Effects of commercial freshwater bathing on reinfection of Altantic salmon, Salmo salar, with amoebic gill disease. Aquaculture 219(1-4): 135-142.

6. Leong TS (1997) Control of parasites in cultured marine finfishes in Southeast Asia - An overview. International Journal Parasitology 27(10): 1177-1184.

7. Cruz Lacierda ER, Toledo JD, Tan Fermin JD, Burreson EM (2000) Marine leech (Zeylanicobdella arugamensis) infestation on cultured orangespotted grouper, Epinephelus coiodes. Aquaculture 185(3-4): 191-196.

8. Burreson EM (1995) Phylum Annelida: Hirudinea as vectors and disease agents [1995]. Protozoan and Metazoan Infections CAB International 1: 599-629.

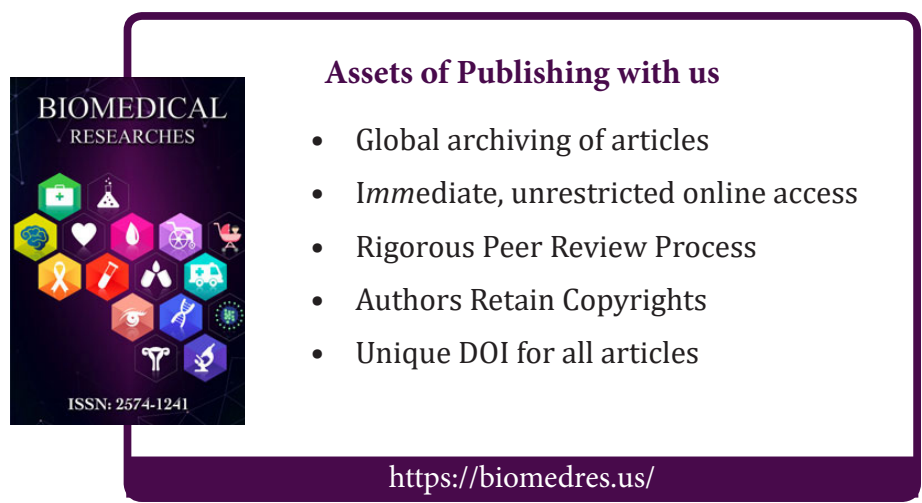

